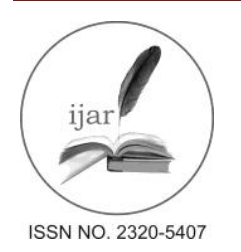

Journal homepage: http://www.journalijar.com

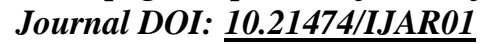

INTERNATIONAL JOURNAL

OF ADVANCED RESEARCH

RESEARCH ARTICLE

\title{
SEASONAL VARIATION IN PHYSICO-CHEMICAL PARAMETERS OF WATER IN ANTIYA TAAL, JHANSI, INDIA.
}

Tirthesh Kumar Sharma And Ramendra Singh.

Department Of Botany And Industrial Microbiology, Bipin Bihari P.G. College, Bundelkhand University, Jhansi, India 284001

\section{Manuscript Info}

Manuscript History:

Received: 12 March 2016

Final Accepted: 22 May 2016

Published Online: May 2016

Key words:

Water quality parameters, physico chemical study, drinking water standards, DO, COD, heavy metals..

*Corresponding Author

Tirthesh Kumar Sharma.

\begin{abstract}
Quality of water is an important criterion for evaluating the suitability of water for drinking and irrigation. The present study was carried out to determine the seasonal variations of physicochemical parameters in water samples from Antiya Taal, Jhansi city, India during August 2014 to May 2015. Seasonal variation of some physico-chemical parameters such as, temperature, $\mathrm{pH}$, salinity, turbidity, conductivity, hardness, chloride contents, alkalinity, total solid, total suspended solid, total dissolved solid, free $\mathrm{CO}_{2}$, dissolved oxygen (DO), chemical oxygen demand(COD), biological oxygen demand (BOD), total organic carbon and heavy metals were determined for the estimation of pollution load. The observations imply that The water of Antiya Taal was found better in the month of November and February compared to that of the month of May.
\end{abstract}

Copy Right, IJAR, 2016,. All rights reserved.

\section{Introduction:-}

Water is the principal need of life on earth, and is an essential component for all forms of lives, including microorganisms animals and plants. The unplanned urbanization and industrialization (Singh et al., 2002) has resulted in over use of environment (Petak, 1980) in particular of water resource. Water is polluted day by day with increasing urbanization and industrialization. Approximately 62.5 million people are suffering from negative effects of Fluorine either by teeth or bones through fluorosis. Generally, water resource problems are of three main types: too little water, two much water and polluted water (Ayoade, 1988 and Adebola, 2001) The precious gift of nature is undoubtedly the water after air, although three fourth part of earth is being surrounded by water a little portion of it can be used for drinking purpose. Any characteristic of water that effects the survival, reproduction, growth and production of aquaculture species, influences management decisions, causes environmental impacts or reduces product quality and safety can be considered a water quality variable. The addition of various kinds of pollutants and nutrients through the agency sewage, industrial effluents, agricultural runoff etc. in to the water bodies brings about a series of changes in the physicochemical and characteristics of water, which have been the subject of several investigations(Mahananda, Mohanty and Behera Mahananda., 2010) For optimum development and management for the beneficial uses, current information is needed which is provided by water quality programmes (Lloyd, 1992). Unequal distribution of water on the surface of the earth and fast declining availability of useable fresh water are the major concerns in terms of water quantity and quality (Boyd \& Tucker, 1998).

The most common standard methods used to assess water quality related to drinking water safety of human contact and for the health of ecosystems. Environmental water quality, also called ambient water quality, relates to water bodies such lakes, river and oceans. Topic substances and high populations of certain microorganisms can present a health hazard for non-drinking purpose such as irrigation, swimming, fishing, boating and industrial uses. The quality of water may be described according to their phycio-chemical and microbiological characteristics. The 
availability of good quality water is an indispensable feature for preventing disease and improving quality of life ( Oluduro and Adewoye, 2007). There is the need to understand the nature and the chemistry of this water, change that may occur due to physical process and anthropogenic activities. Assessment of water resources will not be complete without the knowledge of quality characteristics as assessed by their physical and biological constituents(Caliandro et al,1995). The physico-chemical characteristics of the aquatic environment directly influence the life inhabiting it. Fluctuation in these constituents often create an adverse environment to organisms, limiting their growth and interfering in the physiological processes, which reduce their ability to compete with other populations within the environment, ultimately changing the community structure(Kedar and Patil, 2011).

Present study has been done to assess the seasonal variation in the physico-chemical characteristics of water in the Antiya Taal. Some physicochemical parameters which include temperature, $\mathrm{pH}$, electrical conductivity, salinity, turbidity, total solid, total disolved solid, Total suspended solid, alkalinity, total Hardness, $\mathrm{Ca}^{++}$hardness $\mathrm{Mg}^{++}$ hardness, chloride, free $\mathrm{CO}_{2}$, disolved oxygen, biological oxygen demand, chemical oxygen demand, total organic carbon and heavy metal were determined. The mean values of these parameters were compared with National Standard for Drinking Water Quality (NSDWQ) and U.S. Environmental Protection Agency (USEPA) standards cited in Zeb et al. (2011). Here, the present study was conducted to study the physico-chemical properties of water in the in the Antiya Taal, jhansi U.P. for a period of one year from August 2014 to May 2015.

\section{Material and methods:-}

\section{Study site:-}

Antiya Taal is a water reservoir receiving municipal waste water and sewage from Jhansi city. Lakes are stagnant surface water bodies, receive and stores rain fall water. It is located between latitude $25012^{\prime}$ N-120 16' $\mathrm{N}$ and longitude $78018^{\prime}$ E-780 23'E in Jhansi City, Bundelkhand region, Central India. Taal is shallow with an area of $0.32 \mathrm{Km}^{2}$ and is surrounded by residential houses in all sides.

\section{Sampling:-}

In the present work we report quality of water taken from Antiya Taal during before Monsoon, After mansoon , Spring and Summer seasons for the period the year August 2014 to May 2015 Thus the present study was carried out the over period of one year. The sampling period of four different seasons like pre-monsoon (Aug) post mansoon (Nov) Spring (Feb) and summer (May) for the convenience and easy interpretation of results. The samples were collected in plastic containers they were cleaned with dilute nitric acid and rinsed several times with tap water, and finally rinsed once with sample water and finally collected from the habitat. The samples were stored in a refrigerator. Samples were preserved and analyzed by adopting the procedures outlined by standard methods for various parameters APHA (1989). Two liters of water samples were collected in these containers and tested the physicochemical parameters at industrial microbial laboratory in the department of botany Bipin Bihari college jhansi.

\section{Physico-chemical analysis:-}

Water samples were collected from Antiya Taal during pre-monsoon, post monsoon, spring and summer season. Analysis was carried out for various water quality parameters such as environmental temperature, water temperature, $\mathrm{pH}$, electrical conductivity, salinity, turbidity, total solid, total disolved solid, total suspended solid, alkalinity, total hardness, $\mathrm{Ca}^{++}$hardness, $\mathrm{Mg}^{++}$hardness, chloride, free $\mathrm{CO}_{2}$, disolved oxygen, biological oxygen demand, chemical oxygen demand, total organic carbon and heavy metals using standard methods. (Trivedy and Goel 1986, Manivaskam, 2005). $\mathrm{pH}$ and temperature were determined immediately at the place of collection.

\section{Result and discussion:-}

\section{Environmental temperature and water temperature:-}

The overall range in the enivironmental temperature observed was $12.5-45^{\circ} \mathrm{C}$ while the water temperature was ranged from $9.3-34.5^{\circ} \mathrm{C}$ in which maximum temperature was recorded in the month of May and minimum at november of both. WHO prescribed the limit of drinking water was between 30 to $40^{\circ} \mathrm{C}$. Temperature in water quality test is used as a good measure of contamination as it has marked effect on bacteria and chemical reaction rates in water (Mink,1964, Dixey, 1972, Hutton,1983). 
Ph:-

The $\mathrm{pH}$ for water samples were ranged from 8.2 to 9.15. It was minimum at may and maximum at August. The result indicated that the water resources available to the inhabitants of the area is basic. The Target Water Quality Range (TWQR) for $\mathrm{pH}$ in water for domestic use varied from 6 - 9 .

\section{Electrical conductivity:-}

The electrical conductivity of water sample ranged from 426 to 455 . The maximum value was observed at during the month of Augest and the minimum value was 446 month of February. Electrical conductivity (EC) in natural waters is the normalized measure of the water's ability to conduct electric current. This is mostly influenced by dissolved salts such as sodium chloride and potassium chloride. Measurements of EC reflect the amount of total dissolved solids (TDS) in natural waters.

\section{Salinity:-}

The values for salinity were ranged between $205 \mathrm{mg} / \mathrm{l}$ to $224 \mathrm{mg} / \mathrm{l}$ Which was minimum in February and Maximum in August.

\section{Turbidity:-}

In the present study water turbidity values ranged from 19 to 27 NTU (Table -1 ). turbidity values recorded for all the samples were higher than the FEPA recommended limit of <10/NTU for drinking water. This shows that the water contains a lot of pollutants. High turbidity levels lead to high level of deposition and silt problem in the water were the waste is discharge.

Table 1:- Phsicochemical parameters of water from Antiya Taal during 2014-15

\begin{tabular}{|c|c|c|c|c|c|}
\hline S.No. & Parameters & Aug. (2014) & Nov.(2014) & Feb. (2015) & May. (2015) \\
\hline 1. & Envir. Tem(Tc) & 34.0 & 35.0 & 12.5 & 45.0 \\
\hline 2. & Water $\operatorname{tm}\left(\mathrm{T}^{0} \mathrm{C}\right)$ & 35.4 & 32.5 & 9.3 & 33.5 \\
\hline 3. & $\mathrm{PH}$ & 9.15 & 8.90 & 8.5 & 8.2 \\
\hline 4. & Conductivity(uH) & 455.0 & 444.0 & 426.0 & 437.0 \\
\hline 5. & Salinity & 224.0 & 211.0 & 205.0 & 219.0 \\
\hline 6. & Turbidity(NTU) & 27.0 & 23.0 & 19.0 & 26.0 \\
\hline 7. & TDS(mg/L) & 320.0 & 380.0 & 365.0 & 380.0 \\
\hline 8. & $\mathrm{TS}(\mathrm{mg} / \mathrm{L})$ & 560.0 & 540.0 & 505.0 & 573.0 \\
\hline 9. & $\mathrm{TSS}(\mathrm{mg} / \mathrm{L})$ & 240.0 & 160.0 & 140.0 & 223.0 \\
\hline 11. & Alkalinity(mg/L) & 178.90 & 202.0 & 187.0 & 198.0 \\
\hline 12. & Hardness(mg/L) & 325.5 & 295.0 & 245.0 & 373.0 \\
\hline 13. & $\mathrm{Ca}^{++}$ & 88.0 & 59.50 & 46.0 & 76.0 \\
\hline 14. & $\mathrm{Mg}^{++}$ & 218.50 & 244.0 & 193.0 & 209.0 \\
\hline 15. & Free $\mathrm{CO}_{2}(\mathrm{mg} / \mathrm{L})$ & 0 & 2.86 & 5.35 & 5.90 \\
\hline 16. & Chloride(mg/L) & 63.9 & 60.35 & 54.3 & 64 \\
\hline 17. & $\mathrm{DO}(\mathrm{mg} / \mathrm{L})$ & 2.96 & 2.75 & 3.0 & 2.51 \\
\hline 18. & $\mathrm{BOD}(\mathrm{mg} / \mathrm{L})$ & 34.0 & 38.0 & 35.5 & 41.0 \\
\hline 19. & $\mathrm{COD}(\mathrm{mg} / \mathrm{L})$ & 68.24 & 71.5 & 67.2 & 70.0 \\
\hline 20. & TOC (mg/L) & 31.87 & 34.25 & 36.7 & 34.0 \\
\hline
\end{tabular}

Table 2:- Determination of trace element of water from Antiya Talab 2014- 15

\begin{tabular}{|c|c|c|c|c|c|}
\hline S.No. & Parameters & Aug. (2014) & Nov.(2014) & Feb. (2015) & May. (2015) \\
\hline 1. & $\mathrm{Zn}(\mathrm{mg} / \mathrm{L})$ & 0.0 & 0.0 & 0.0 & 0.0 \\
\hline 2. & $\mathrm{~Pb}(\mathrm{mg} / \mathrm{L})$ & 0.0 & 0.0 & 0.0 & 0.0 \\
\hline 3. & $\mathrm{Fe}(\mathrm{mg} / \mathrm{L})$ & 0.32 & 0.36 & 0.34 & 0.35 \\
\hline
\end{tabular}

Total Solid, Total disolved solid, Total suspended solid:-

The average total dissolved solids(TDS) value for the analysis, revealed a value of ranged maximum 380 and minimum $320 \mathrm{mg} / \mathrm{I}$. Total suspended solids (TSS) are defined as the portion of total solids in a water sample retained by a glass fibre $(\mathrm{GF} / \mathrm{C})$ filter of pore size $>2 \mu \mathrm{m}$. The values for the total suspended solid (TSS) was maximun of $240 \mathrm{mg} / \mathrm{l}$ and minimum $140 \mathrm{mg} / \mathrm{l}$ This shows that the TSS for all the season of water sample was 
above FEPA limit of $30 \mathrm{mg} / \mathrm{l}$.TS was also recored maximum in the month of August and minimum in February. It was 560mg/l in August and 505mg/l in February.

Alkalinity:-

The alkalinity values were found between $178.9 \mathrm{mg} / \mathrm{l}$ to $202 \mathrm{mg} / \mathrm{l}$, all the samples were within the permissible limits of WHO which was $200 \mathrm{mg} / \mathrm{l}$. The variation of Alkalinity is in accordance with fluctuation in pollution load (Parashar et al., 2006)

Total hardness, $\mathrm{Ca}^{++}$hardness, $\mathrm{Mg}^{++}$hardness:-

Hardness is an important parameter in decreasing the toxic effect of poisonous element. Total hardness were ranged between $195 \mathrm{mg} / \mathrm{l}$ (February) to $373 \mathrm{mg} / \mathrm{l}$ (May). $\mathrm{Ca}^{+2}$ and $\mathrm{Mg}^{+2}$ are important contributors to water hardness. Calcium $\left(\mathrm{Ca}^{2+}\right)$ and magnesium $\left(\mathrm{Mg}^{2+}\right)$ ions are both common in natural water and both are essential elements for all organisms. Calcium and magnesium, when combined with bicarbonate, carbonate, sulphate and other species, contribute to the hardness of natural waters. The effect of this hardness can be seen as deposited scale when such waters are heated. Normally hardness due to calcium predominates although in certain regions, magnesium hardness can be high. So result show that $\mathrm{Mg}^{++}$hardness were ranged between $193 \mathrm{mg} / \mathrm{l}$ (February) to $244 \mathrm{mg} / \mathrm{l}$ (August) and $\mathrm{Ca}^{++}$hardness were ranged between $46 \mathrm{mg} / 1$ (February) to $88 \mathrm{mg} / \mathrm{l}$ (August)

\section{Chloride:-}

Chloride concentration in water indicates presence of organic waste particularly of animal origin (Thresh et. al, 1949) Increase in chloride concentration on discharge of municipal and industrial waste has been reported (Ownby and Kee, 1967). In our present study maximum $\mathrm{Cl}^{-}$contents are found to be $64 \mathrm{mg} / \mathrm{l}$ in summer season (May) and minimum $54.5 \mathrm{mg} / \mathrm{l}$ in the month February. Chloride prescribed by WHO which is $250 \mathrm{mg} / \mathrm{l}$. This High chloride contents in water makes it taste salty and also promote pipe corrosion .

\section{Free $\mathrm{CO}_{2:-}$}

The value of free $\mathrm{CoO}_{2}$ ranges from $0.0 \mathrm{mg} / \mathrm{l}$ to $5.90 \mathrm{mg} / \mathrm{l}$. The maximum value $(5.90 \mathrm{mg} / \mathrm{l})$ was recorded in the month of May and minimum value $(0.0 \mathrm{mg} / \mathrm{l})$ in the month of August. This may be depends upon alkalinity and hardness of water body. The value of $\mathrm{CO}_{2}$ was high in May. This could be related to the high rate of decomposition in the warmer months.

\section{Disolved oxygen:-}

Dissolved oxygen is an important aquatic parameter, whose presence is vital to aquatic fauna. It plays crucial role in life processes of animals. In our study the DO values found to be maximum was $3.0 \mathrm{mg} / \mathrm{l}$ in month of February and minimum in the month of May was $2.51 \mathrm{mg} / \mathrm{l}$. This values of DO Show the minimum quantity of phytoplankton in summer and consumer of $\mathrm{O}_{2}$ was maximum.

\section{Biological oxygen demand:-}

BOD is a value of presence of organic materials in water which can support increasing of microbe organisms. Lowest BOD content as $34 \mathrm{mg} / \mathrm{l}$ at Antiya Taal was recorded in August and highest BOD was recorded in the month of May was $41 \mathrm{mg} / \mathrm{l}$

\section{Chemical oxygen demand:-}

In environmental chemistry, the chemical oxygen demand (COD) test is commonly used to indirectly measure the amount of organic compounds in water. Most applications of COD determine the amount of organic pollutants found in surface water making COD a useful measure of water quality. It is expressed in milligrams per litre (mg/l), which indicates the mass of oxygen consumed per litre of solution.

The COD is a measure of oxygen equivalent to the organic matter content of the water susceptible to oxidation by a strong chemical oxidant and thus is an index of organic pollution in the Taal. The COD level at Antiya Taal were $68.24 \mathrm{mg} / \mathrm{l}$ (August), $71.5 \mathrm{mg} / \mathrm{l}$ (November), 67.2mg/l (February), 70.0mg/l (May)

Total organic carbon:-

TOC recorded as range from 31.87 to $36.7 \mathrm{mg} / \mathrm{l}$. It was maximum in Spring and minimum in before mansoon 


\section{Heavy metal:-}

Zinc and lead were nil in Water samples of Antiya Taal and iron was recored as maximum $0.36 \mathrm{mg} / \mathrm{l}$ and minimum $0.32 \mathrm{mg} / \mathrm{l}$ in the month of August

\section{Acknowledgements:-}

The authors are very thankful to the UGC, New Delhi, for financial support and Principal, Bipin Bihari PG degree college, Jhansi for providing necessary research facilities.

\section{Acknowledgements:-}

1. Adebola, K. D. (2001). Groundwater Quality in Ilorin Township: An Environmental Review African Journal of Environmental Studies. 2(2) 4-

2. APHA, (1989). American Public health Association], AWWA [American Water Works Association] and WPCF [Water Pollution Control Federation] standard method for examination of water and waste water 17th Edn. American Public Health Association, Washington, D.C. 20005,.

3. Ayoade, J. O. (1988), Tropical Hydrology and Water Resources. London and Basingstoke, Macmillan.

4. Boyd, C.E. and C.S. Tucker, (1998). Pond aquaculture and water qualityv management. pp: 44-8. Kluwer Academic Pub., London

5. Caliandro, A., Hamdy,A., Lacirignola, C. and Catalano, M (1995) "Environmental Impacts of Water Resources Development and management", CIHEAM-Options, Mediterraneens..

6. Dixey, F.A (1972) “A Practical Handbook om Water Supply”,2nd edition, Murby, London

7. Hutton, L (1983) "Field testing of water in developing countries", Water Resources Center, Unwin Brothers Limited, Britain.

8. KEDAR, G.T. and PATIL,G.P.(2011) Study on seasonal fluctuation in physico-chemical parameters of Rishi lake, Karanja (Lad),

9. Lloyd, R. 1992. Pollution and Fresh Water Fish, Fishing News Books

10. Mahananda, M. R., Mohanty, B.P. and Behera Mahananda N. R.(2010) Physico-Chemical Analysis of Surface and Ground Water of Bargarh District, Orissa, India, IJRRAS, 2 (3)

11. Manivaskam N. (2005) Physicochemical examination of water sewage and industrial effluent, 5th Ed. Pragati Prakashan Meerut.,

12. Mink, J. F. (1964) “Groundwater Temperatures in tropical Island environment”, Journal of Geophysical Research, Vol.66, pp.52230-5250.

13. Oluduro, A.O. and Adewoye, B.I. (2007) Efficiency of moringa oliefera sead extract on the micro flora of surface and ground water J. Plant Sci. 6. pp. 453-438.

14. Ownby C.R. and Kee ,D.A. (1967) Chloride inlake Eric.Proc. Cong. Grat Lakes,:382-389

15. Parashar, C. Dixit, S. Srivastva, R.(2006) Seasonal variations in Physico-chemical characteristics in upper lake of Bhopal, Asian .J. Exp. Sci., 20(2):297-302

16. Salam, A. and Rizvi, S.M. (1999). Studies on biodiversity and water quality parameters of Chenab River Muzaffargarh. Semi. Aqua. Bio. Pakistan, Karachi. 17

17. Singh S.P., Pathak D. and Singh R.( 2002)Eco. Env. And Cons., ,8(3),:289-292.

18. Petak W.J. (1980) Environ. Managem., 4, 287-295.

19. Thresh J.C., Beale J.F. and Suckling E.V (1949) The examination of water and water supplies B.W. Taylor, London.

20. Trivedy R.K. and Goel P.K. (1986)Chemical and Biological methods for water pollution studies Environmental Publication, Karad,

21. Zeb, B.S., Malik, A.H., Waseem A. and Mahmood, Q. (2011). Water quality assessment of Siran river, Pakistan. Int. J. Phys. Sci., 6: 7789-7798. 